\title{
Prioritization of Soil Erosion Vulnerable Areas Using Multi-Criteria Analysis Methods
}

\author{
Tijana Vulević' ${ }^{*}$, Nada Dragović ${ }^{1}$, Stanimir Kostadinov ${ }^{1}$, \\ Snežana Belanović Simić1, Irina Milovanović \\ 'Faculty of Forestry, University of Belgrade, Kneza Višeslava 1, 11000 Belgrade, Serbia \\ ${ }^{2}$ The Jaroslav Černi Institute for the Development of Water Resources (JCI), \\ Jaroslava Černog 80, 11226 Pinosava, Belgrade, Serbia
}

Received: 10 April 2014

Accepted: 3 August 2014

\begin{abstract}
Soil erosion caused by natural or anthropogenic factors represents a widespread problem with a range of negative environmental consequences. Various measures and works are being carried out to mitigate and prevent the direct and indirect effects of erosion. These actions often cannot be implemented in a whole region prone to erosion due to limited financial or human resources. Therefore, identifying the area that requires particular attention for conservation is necessary. The objective of this paper was to determine the most vulnerable areas (sub-watersheds) to soil erosion in the Topčiderska River Watershed, located in northern Serbia, using available data: land use, soil characteristics, and mean watershed slope. Using such multi-criteria decision analysis methods as analytic hierarchy process (AHP) and technique for order preference by similarity to ideal solution (TOPSIS), the most vulnerable sub-watersheds were determined for three different scenarios. The results show a strong correlation between the ranking based on AHP method and TOPSIS method. It is observed that the most vulnerable sub-watersheds are characterized by the significant presence of arable land and very steep slope and thus have priority for conservation.
\end{abstract}

Keywords: soil erosion, conservation priority, sub-watershed, AHP method, TOPSIS method

\section{Introduction}

Soil erosion is a complex problem affected by numerous factors such as topography, climate, soil characteristics, soil cover, and human activities. Some of the consequences of this phenomenon are reducing soil productivity, impaired water quality, and increased flood risk [1]. Due to its omnipresence in time and space and numerous negative influences on the environment, soil erosion is considered to be one of the most serious worldwide problems [2, 3]. It is also registered as one of the most frequently occurring natural hazards within the territory of Serbia [4]. In order to protect the environment and reduce the negative effects of

*e-mail: tijana.andrijanic@sfb.bg.ac.rs erosion on agriculture, infrastructure, water quality, etc., it is necessary to carry out the actions of soil and water conservation [5]. This shows the need for making decisions about the parts of the watershed area that require an urgent intervention and where it is necessary to direct available human and financial resources [6].

Numerous authors were dealing with the problem of determining areas vulnerable to erosion that have priority for conservation [2, 5, 7, 8]. Zhang et al. [5] ranked the areas in the watershed according to the priority of conservation by three criteria: vegetation cover, land use, and slope gradient. Vrieling et al. [9] analyzed regional erosion risk using two factors: slope gradient and vegetation cover.

Assessment of the current erosion rate is carried out at different scale levels (field, watershed) applying different 
empirical, conceptual, and physical models [10]. Some of the shortcomings of these methods include requiring a lot of data that are scarce in the databases of developing countries, or they are limited to the areas for which the methods have been developed [11].

The aim of this paper was to rank the sub-watersheds according to their vulnerability to erosion using three factors (slope gradient, land use, and soil types) applying the methods of multi-criteria decision analysis (MCDA): analytic hierarchy process (AHP) and technique for order preference by similarity to ideal solution (TOPSIS). The AHP method is proven as effective in solving complex decision problems such as risk of soil erosion $[12,13]$. The result of the application of these methods can be used to identify sub-watersheds recognized as a priority area for conservation actions.

\section{Materials and Methods}

\section{Study Area}

The selected study area is the Topčiderska River Watershed located in the northern part of Serbia (Fig. 1). This region, covering an area about $147 \mathrm{~km}^{2}$ is characterized by the presence of many tributaries. Erosion processes in the 20 sub-watersheds registered in this area cause great damage such as soil and water losses, flooding, waterlogging, and siltation of accumulation and melioration systems. Therefore, it is significant to decide which sub-watershed presents the priority area for conservation to reduce the intensity of erosion processes.

\section{Identification of the Factors For Soil Erosion Vulnerability Assessment}

For 20 registered tributaries, using topographic maps of $1: 25,000$ and 1:50,000 scale and orthophoto images of 1:5 000 scale the mean sub-watershed slope, soil types, and land use/cover are determined. Since these factors represent one of the core causes of erosion processes, they were taken as the criteria for predicting soil erosion vulnerability (Table 1). Six classes of land use/cover are registered in the watershed area: arable land, meadows, urbanized area, forests, degraded forests, reservoirs, and industrial area (Fig. 2a). There are eight soil types in the watershed area of the Topčiderska River: luvisol, cuntanic cambisol (eutric), eutric cambisol, colluvial deposit, luvic chernozem, vertisol, fluvisol, and lithic leptosol (Fig. 2b). Susceptibility of these soil types to erosion, denoted as a K factor (Fig. 3), based on soil texture (content of silt, sand, and clay fraction) and organic carbon content in the surface soil layers $(0-30 \mathrm{~cm})$ is estimated using the equation given in the EPIC model [14]. The third parameter used for assessing the vulnerability to erosion was a topographic parameter - mean watershed slope and its values are displayed in Table 1.

\section{AHP Method}

The AHP method, developed by the mathematician Thomas L. Saaty, was used to rank the vulnerability of subwatersheds because it is characterized by fine mathematical properties and requires input data that are easily obtained [15]. This method is a robust and flexible decision-making tool that is used for finding solutions of complex multi-cri-

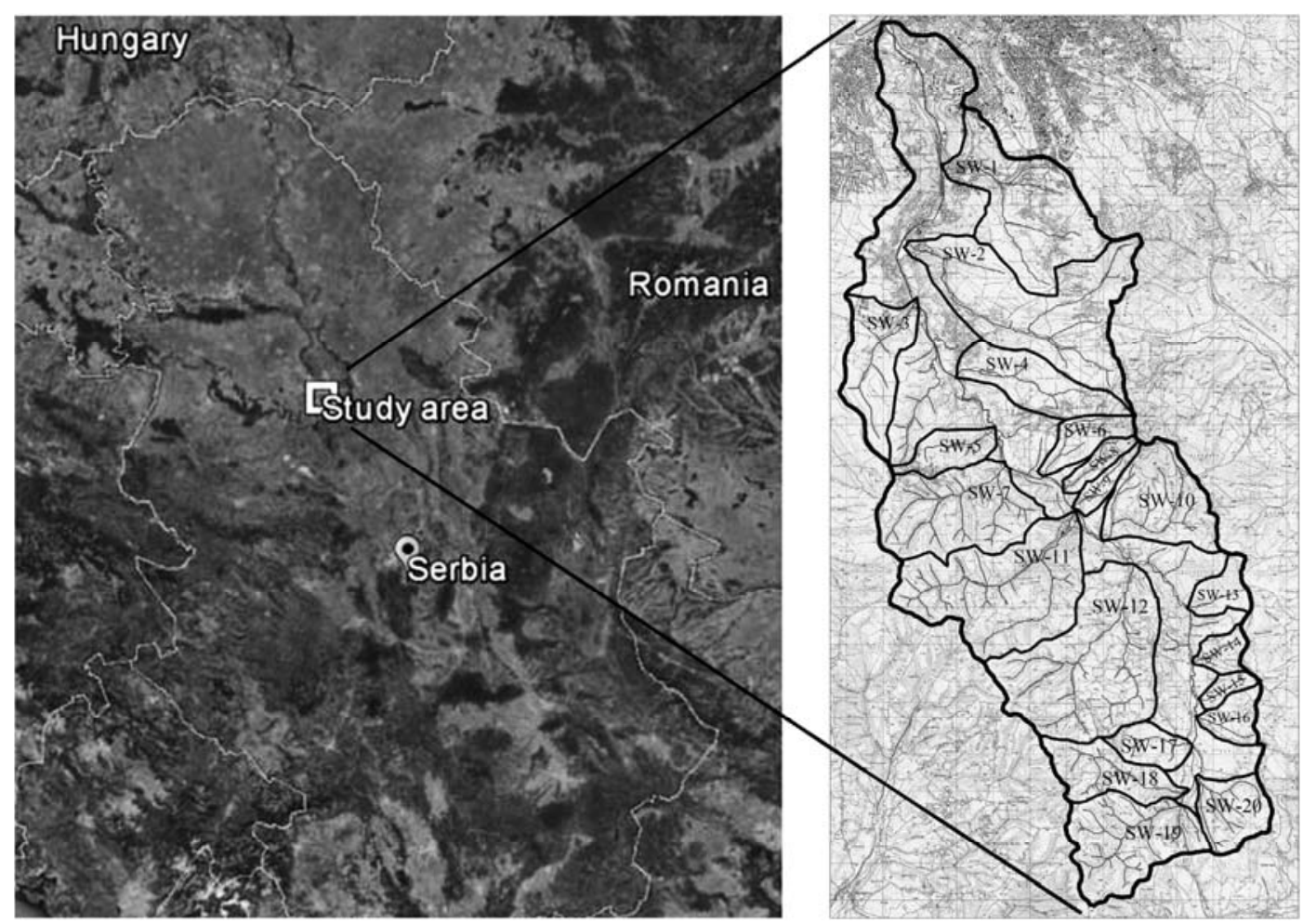

Fig. 1. Study area: Topčiderska River Watershed divided into sub-watersheds. 
Table 1. Values of the factors used in the study.

\begin{tabular}{|c|c|c|c|}
\hline $\begin{array}{c}\text { Sub-water- } \\
\text { shed }\end{array}$ & $\begin{array}{c}\text { Mean sub- } \\
\text { watershed } \\
\text { slope S (\%) }\end{array}$ & $\begin{array}{c}\text { Land use } \\
\text { (LU) factor }\end{array}$ & $\begin{array}{c}\text { Soil type } \\
\text { (ST) factor }\end{array}$ \\
\hline SW-1 & 17.42 & 18.4291 & 6.3306 \\
\hline SW-2 & 17.12 & 30.1252 & 9.0485 \\
\hline SW-3 & 21.71 & 25.2956 & 14.3022 \\
\hline SW-4 & 27.36 & 31.7667 & 8.7043 \\
\hline SW-5 & 26.94 & 20.1592 & 13.2607 \\
\hline SW-6 & 39.39 & 25.7653 & 19.3844 \\
\hline SW-7 & 22.14 & 19.1281 & 14.7350 \\
\hline SW-8 & 46.29 & 16.5870 & 22.7208 \\
\hline SW-9 & 45.64 & 24.9181 & 11.7860 \\
\hline SW-10 & 26.66 & 15.0065 & 16.8339 \\
\hline SW-11 & 19.59 & 26.7233 & 12.9381 \\
\hline SW-12 & 19.26 & 25.0759 & 13.9277 \\
\hline SW-13 & 29.04 & 18.2586 & 10.4707 \\
\hline SW-14 & 28.75 & 21.2412 & 16.7698 \\
\hline SW-15 & 13.63 & 24.8897 & 10.5511 \\
\hline SW-16 & 25.60 & 29.4865 & 6.0599 \\
\hline SW-17 & 28.12 & 31.2648 & 17.8956 \\
\hline SW-18 & 23.31 & 26.0613 & 18.3425 \\
\hline SW-19 & 19.48 & 17.2097 & 21.2649 \\
\hline SW-20 & 32.45 & 19.6290 & 9.7459 \\
\hline
\end{tabular}

(a)

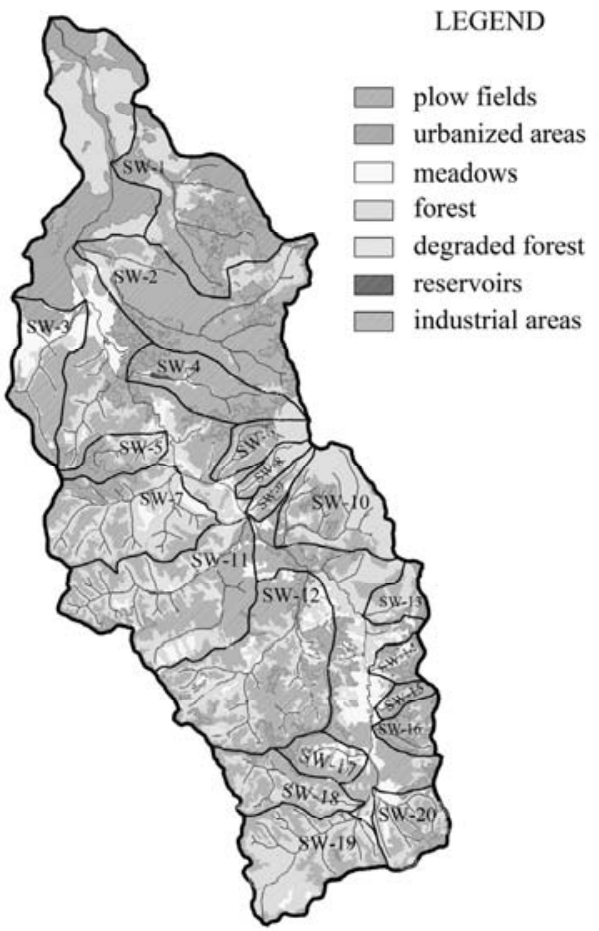

teria problems such as a determining the priority of conservation practices [16-18], landslide susceptibility mapping [19], or soil erosion risk assessment [2, 12, 13].

The AHP method consists of four steps:

(1) Structure the problem into a hierarchy having different levels, i.e., goal, criteria, sub-criteria, and alternatives

(2) Make pair-wise comparison matrices $A=\left[a_{i j}\right] n \times n$, where $n$ is matrix size and $a_{i j} \geq 0 \quad a_{i j} \times a_{j i}=1, a_{i j}$-importance of the ith decision factors over the $j$ th decision factors

(3) Calculate the relative weights (priorities) of decision factors using prioritization method, e.g. eigenvalue (EV) method [20]

(4) Make synthesis of the priorities. All matrices must satisfy consistency test, i.e., judgment matrices are accepted if consistency ratio (CR) obtained using consistency index $(\mathrm{CI})$ and random index (RI) is less than 0.10 .

\section{TOPSIS Method}

Besides the AHP method, the TOPSIS method developed by Hwang and Yoon in 1981 is used to test the robustness of the results. Behzadian et al. [21] give a literature survey of TOPSIS method applications. The basic idea of the TOPSIS method is a comparison of alternatives based on aggregates of two types of information: the distance from the positive and negative ideal solution [22]. The procedure of the TOPSIS method consists of five steps [23, 24]:

(1) Construct the normalized decision matrix $R=\left(r_{i j}\right)_{m \times n}$, where $r_{i j}(i=1,2, \ldots, m)$ is the normalized value for benefit or for cost criteria

(2) Construct the weighted normalized decision matrix, where the weighted normalized value $v_{i j}$ is obtained as (b)

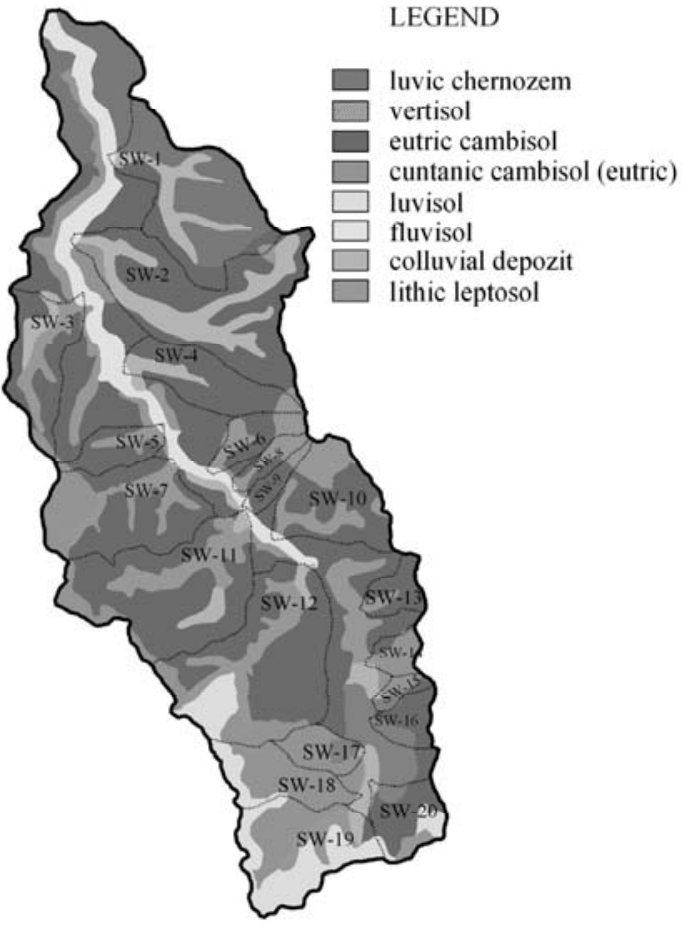

Fig. 2. Spatial distibution of (a) different ways of land use/covers and (b) soil types registered into study area. 
Table 2. Results of pair-wise comparison of criteria.

\begin{tabular}{|c|c|c|c|c|c|}
\hline Criteria & Weights & $\lambda_{\max }$ & $C I$ & $R I$ & $C R$ \\
\cline { 1 - 2 } Land use & 0.7142 & & & & \\
\cline { 1 - 2 } Soil type & 0.1429 & \multirow{2}{*}{3} & 0 & 0.58 & 0 \\
\cline { 1 - 2 } Slope & 0.1429 & & & & \\
\hline
\end{tabular}

$\lambda_{\max }-$ maximum value of eigenvector; $C I$ - consistency index; $R I$ - random consistency index, $C R$ - consistency ratio

$v_{i j}=w_{j} r_{i j}$, where $w_{j}$ represents weights of decision factors

(3) Determine the positive ideal solution (PIS) and negative ideal solution (NIS): $A^{+}=\left\{v_{1}^{+}, v_{2}^{+}, \ldots v_{n}^{+}\right\}$and $A^{-}=\left\{v_{1}^{-}\right.$, $\left.v_{2}^{-}, \ldots v_{n}^{-}\right\}$, where $v_{j}^{+}$is the maximum value for benefit criteria, and minimum value for cost criteria and $v_{j}^{-}$minimum value for benefit criteria and maximum value for cost criteria
(4) Calculate the separation of each alternative from the ideal $D_{j}^{+}=\sqrt{\sum_{i=1}^{n}\left(v_{i j}-v^{+}\right)^{2}}$ and negative ideal solution $D_{j}^{-}=\sqrt{\sum_{i=1}^{n}\left(v_{i j}-v^{-}\right)^{2}}$

(5) Calculate the relative closeness to the ideal solution $C_{j}^{+}=D_{j}^{-} / D_{j}^{+}+D_{j}^{-}$

(6) Rank the preference order.

\section{Results and Discussion}

We started with AHP procedure and the first step was to determine the overall goal of the decision process. The problem is determined as a selection of the most vulnerable sub-watersheds to soil erosion based on influencing factors: slope, land use, and soil type. These criteria (factors) are decomposed into sub-criteria (six land use classes and eight soil types).

Table 3. Results of pair-wise comparisons of sub-criteria.

\begin{tabular}{|c|c|c|c|c|c|c|}
\hline Criteria & Sub-criteria & Weights & $\lambda_{\max }$ & $C I$ & $R I$ & $C R$ \\
\hline \multirow{6}{*}{ Land use } & Arable land & 0.4324 & \multirow{6}{*}{6.3976} & \multirow{6}{*}{0.0795} & \multirow{6}{*}{1.24} & \multirow{6}{*}{0.0641} \\
\hline & Degraded forests & 0.2490 & & & & \\
\hline & Meadows & 0.1332 & & & & \\
\hline & Industrial areas & 0.0872 & & & & \\
\hline & Urbanized areas & 0.0686 & & & & \\
\hline & Forests & 0.0296 & & & & \\
\hline \multirow{8}{*}{ Soil type } & Lithic leptosol & 0.3148 & \multirow{8}{*}{8.6760} & \multirow{8}{*}{0.0966} & \multirow{8}{*}{1.41} & \multirow{8}{*}{0.0685} \\
\hline & Luvisol & 0.2177 & & & & \\
\hline & Cuntanic cambisol & 0.1147 & & & & \\
\hline & Colluvial deposit & 0.1820 & & & & \\
\hline & Eutric cambisol & 0.0722 & & & & \\
\hline & Luvic chernozem & 0.0419 & & & & \\
\hline & Vertisol & 0.0232 & & & & \\
\hline & Fluvisol & 0.0335 & & & & \\
\hline
\end{tabular}

$\lambda_{\max }$ - maximum value of eigenvector; $C I$ - consistency index; $R I$ - random consistency index, $C R$ - consistency ratio

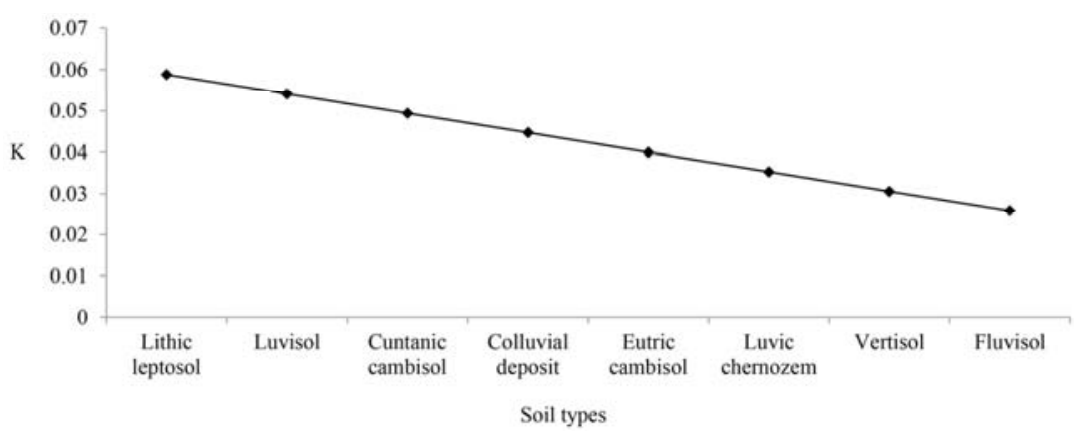

Fig. 3. Soil erodibility ( $\mathrm{K}$ - factor) for different soil types. 
Table 4. Results of the AHP method.

\begin{tabular}{|c|c|c|c|c|}
\hline \multirow{2}{*}{$\begin{array}{c}\text { Sub- } \\
\text { watersheds }\end{array}$} & \multicolumn{3}{|c|}{ Weights of alternatives (sub-watersheds) $d_{i}$} & \multirow{2}{*}{$\begin{array}{c}\text { ER } \\
\text { value }\end{array}$} \\
\hline & $d_{l u}$ & $d_{s t}$ & $d_{s}$ & \\
\hline SW-1 & 0.0401 & 0.0230 & 0.0329 & 0.0367 \\
\hline SW-2 & 0.0647 & 0.0338 & 0.0323 & 0.0557 \\
\hline SW-3 & 0.0534 & 0.0516 & 0.0410 & 0.0514 \\
\hline SW-4 & 0.0682 & 0.0323 & 0.0516 & 0.0607 \\
\hline SW-5 & 0.0434 & 0.0478 & 0.0508 & 0.0451 \\
\hline SW- 6 & 0.0553 & 0.0686 & 0.0743 & 0.0599 \\
\hline SW-7 & 0.0408 & 0.0531 & 0.0418 & 0.0427 \\
\hline SW-8 & 0.0351 & 0.0800 & 0.0874 & 0.0490 \\
\hline SW-9 & 0.0529 & 0.0426 & 0.0861 & 0.0562 \\
\hline SW-10 & 0.0317 & 0.0599 & 0.0503 & 0.0384 \\
\hline SW-11 & 0.0577 & 0.0470 & 0.0370 & 0.0532 \\
\hline SW-12 & 0.0540 & 0.0506 & 0.0363 & 0.0510 \\
\hline SW-13 & 0.0387 & 0.0382 & 0.0548 & 0.0409 \\
\hline SW-14 & 0.0466 & 0.0623 & 0.0543 & 0.0499 \\
\hline SW-15 & 0.0533 & 0.0392 & 0.0257 & 0.0473 \\
\hline SW-16 & 0.0633 & 0.0223 & 0.0483 & 0.0553 \\
\hline SW-17 & 0.0670 & 0.0667 & 0.0531 & 0.0650 \\
\hline SW-18 & 0.0558 & 0.0682 & 0.044 & 0.0580 \\
\hline SW-19 & 0.0368 & 0.0769 & 0.0368 & 0.0422 \\
\hline SW-20 & 0.0418 & 0.0359 & 0.0612 & 0.0437 \\
\hline
\end{tabular}

$d_{l u}-$ weights regarding land use (LU); $d_{s t}-$ weights regarding soil types (ST); $d_{s}-$ weights regarding mean subwatershed slope (S)

For all decision factors, judgment matrices are formed. Elements on the same level are pair-wise compared by experts (soil and water conservation specialist). All criteria and sub-criteria are pair-wise compared using a 1-9 scale (1 - equally important, 3 - moderately more important, 5 strongly more important, 7 - very strong more important, 9 - extremely more important, and 2, 4, 6, and 8 intermediately more important). The EV method is used to established priorities (weights) of decision elements [25]. Pairwise comparisons for criteria are completely consistent (the largest eigenvalue $\lambda_{\max }=n=3$ ) and weights for criteria land use, soil type, and slope are, respectively: 0.7142, 0.1429, and 0.1429 . The results of the pair-wise comparisons of criteria and sub-criteria are summarized in Tables 2 and 3 . Alternatives are pair-wised compared using numerical value of slope, LU (land use) factor, and ST (soil type) factor. These factors given in Table 1 are calculated using subcriteria weights (Table 3) and their percentage presence in sub-watershed (Fig. 2): $\sum\left(w_{\text {sub }} \cdot A_{\text {sub }}\right)$. All the matrices satisfy the consistency test, i.e. consistency ratio $\mathrm{CR} \leq 0.10$. The final result of this process was ranking of the 20 sub-water-
Table 5. Positive ideal solution $\left(A^{+}\right)$and negative ideal solution $\left(A^{-}\right)$.

\begin{tabular}{|c|c|c|c|}
\hline & LU & ST & S \\
\hline$A^{+}$ & 0.0530 & 0.0485 & 0.2129 \\
\hline$A^{-}$ & 0.0156 & 0.0135 & 0.0990 \\
\hline
\end{tabular}

LU - land use, ST - soil type, S - mean sub-watershed slope

sheds using vulnerability index ER, which is obtained by multiplying the criteria weights $\left(w_{i}\right)$ and alternative weights $\left(d_{i}\right)$ (Table 4), thus $E R=\sum\left(w_{L U} \cdot d_{L U}+w_{S T} \cdot d_{S T}+w_{S} \cdot d_{S}\right)$ (Table 4). The higher value of $E R$ indicates increased vulnerability to erosion.

A ranking of sub-watershed is then determined using the TOPSIS method, whose procedure starts using the weights obtained by the AHP method (Table 4). Decision matrices $X=\left(X_{i j}\right)_{m \times n}$ are formed where $x_{i j}$ is the score of
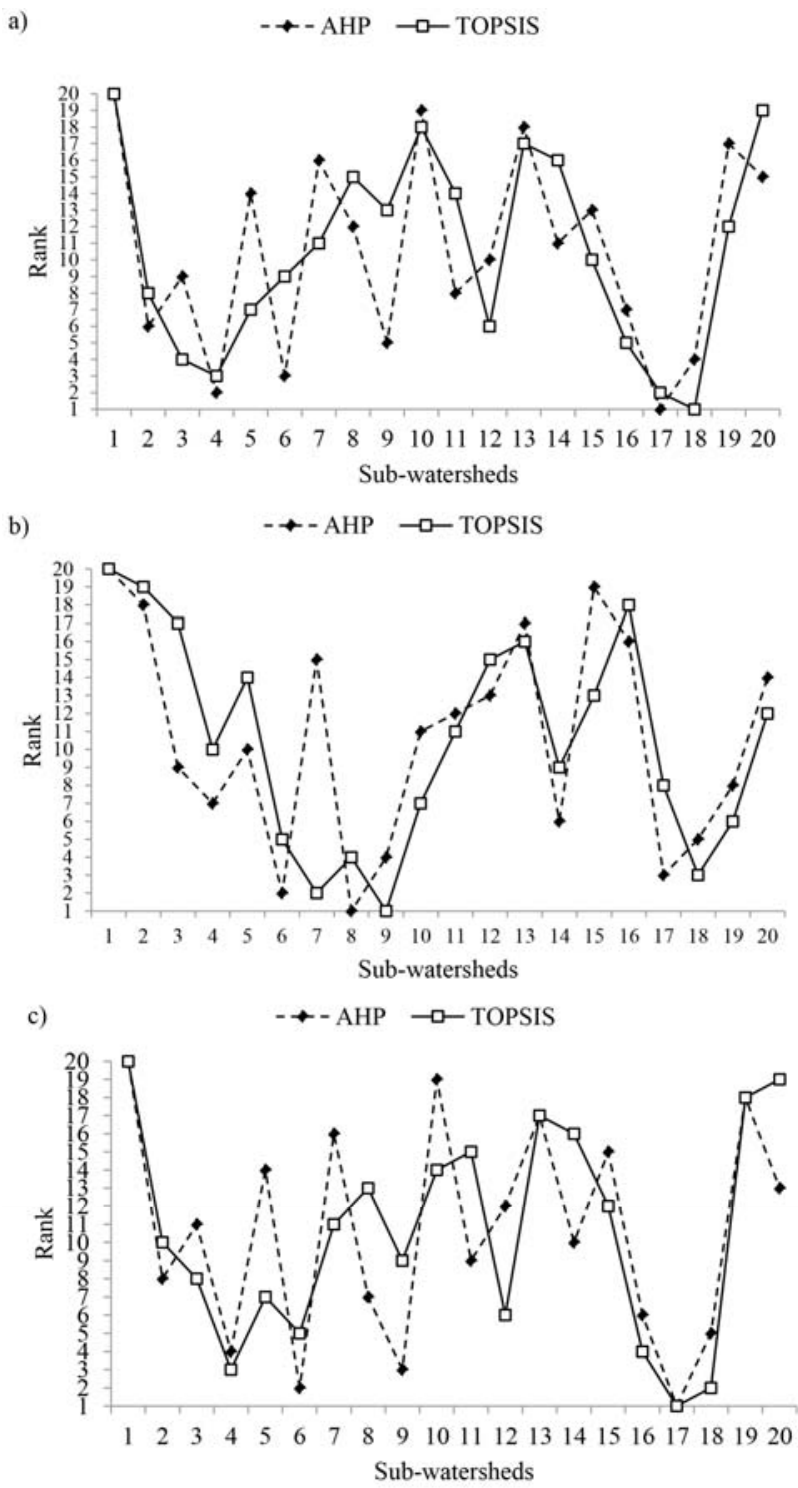

Fig. 4. Comparison of sub-watershed ranking applying AHP and TOPSIS methods according to (a) Scenario 1, (b) Scenario 2 and, (c) Scenario 3. 
Table 6. Relative closeness to the ideal solution $\left(C_{j}^{+}\right)$based on the distance of each alternative (sub-watershed) to the positive ideal solution $\left(D_{j}^{+}\right)$and negative ideal solution $\left(D_{j}^{-}\right)$

\begin{tabular}{|c|c|c|c|c|c|c|c|}
\hline Alternatives & $D_{j}^{+}$ & $D_{j}^{-}$ & $C_{j}^{+}$ & Alternatives & $D_{j}^{+}$ & $D_{j}^{-}$ & $C_{j}^{+}$ \\
\hline SW-1 & 0.5180 & 0.0265 & 0.0487 & SW-11 & 0.1168 & 0.0829 & 0.4151 \\
\hline SW-2 & 0.0999 & 0.1032 & 0.5081 & SW-12 & 0.0491 & 0.0719 & 0.5945 \\
\hline SW-3 & 0.0450 & 0.0707 & 0.6111 & SW-13 & 0.0570 & 0.0298 & 0.3432 \\
\hline SW-4 & 0.0567 & 0.1152 & 0.6700 & SW-14 & 0.0974 & 0.0551 & 0.3614 \\
\hline SW-5 & 0.0362 & 0.0425 & 0.5405 & SW-15 & 0.0713 & 0.0681 & 0.4884 \\
\hline SW-6 & 0.0828 & 0.0841 & 0.5038 & SW-16 & 0.0647 & 0.0994 & 0.6057 \\
\hline SW-7 & 0.0417 & 0.0353 & 0.4582 & SW-17 & 0.0450 & 0.1147 & 0.7181 \\
\hline SW-8 & 0.0915 & 0.0524 & 0.3640 & SW-18 & 0.0226 & 0.0808 & 0.7813 \\
\hline SW-9 & 0.1033 & 0.0765 & 0.4256 & SW-19 & 0.0475 & 0.0367 & 0.4259 \\
\hline SW-10 & 0.0530 & 0.0273 & 0.3396 & SW-20 & 0.1043 & 0.0389 & 0.2718 \\
\hline
\end{tabular}

alternative $i$ with respect to criteria $j$ calculated by the AHP method. In the next step decision matrices are normalized, and weighted normalization matrices are constructed in order to determine PIS and NIS (Table 5). These values are used to calculate relative clossenes to the ideal solution $\left(C_{j}^{+}\right)$based on which sub-watersheds are ranked (Table 6).

The stability of the final ranking of the alternatives highly depends on the weights given to the main criteria. To check the stability of the results a sensitivity analysis is performed. Three scenarios are considered:

Scenario 1: Criteria land use has a strong dominance over both slope gradient and soil type $\left(w_{L U}=0.7143 ; w_{S T}=\right.$ $\left.w_{S}=0.1429\right)$.

Scenario 2: All criteria have the same weighs $\left(w_{L U}=w_{S T}\right.$ $=w_{S}=0.3333$ ).

Scenario 3: Land use criteria has a moderate importance respect to the slope criteria and strong importance respect to criteria - soil types $\left(w_{L U}=0.6334 ; w_{S T}=0.1062\right.$, $\left.w_{S}=0.2605\right)$.

According to Scenario 1, the AHP method ranks SW17, SW4, SW6, SW18, and SW9 as the most vulnerable subwatersheds to soil erosion, while the TOPSIS method ranks sub-watersheds as follows: SW18, SW17, SW4, SW3, and SW16. Comparison of the ranking from AHP and TOPSIS method for all three scenarios is shown in Fig. 4. The Spearman coefficient of correlation calculated, and results show a strong correlation between the ranking based on AHP method and ranking based on TOPSIS method: 0.7323 (Scenario 1), 0.7038 (Scenario 2), and 0.7293 (Scenario 3).

Applying this method we found out that the sub-watersheds that have priority for conservation (SW17, SW18, SW6, SW4, and SW9) are characterized by the significant presence of arable land (more than 50\%) and very steep slope (more than 25\%). This finding coincides with the results of Zhang X. et al. [5] and Nigel R. and Rughooputh S. [8].

\section{Conclusion}

In this study the sub-watersheds were ranked according to erosion vulnerability due to existing land use, soil types, (their texture and carbon content) and mean sub-watershed slope by using the AHP and TOPSIS methods. The applied methods provided similar scores. Both methods rank SW17, SW18, SW6, SW4, and SW9 as the most vulnerable areas that have priority for conservation. Sensitivity analysis, which has been performed, gives information about the stability of the alternative ranking. The example displayed based on available information and expert knowledge, one may determine the most vulnerable areas in the watershed. Identification and prioritization of these areas is an important tool for natural resource management planning because it allows researchers to implement conservation strategies more rationally and sustainably in the longterm. Identification and selection of works and measures, whose implementation is necessary in the most vulnerable areas by using the multiple-criteria decision-making methods, is an issue to be addressed in future research.

\section{Acknowledgements}

This paper is a part of Project No. 43007, subproject No. 16., funded by the Ministry of Education, Science, and Technological Development of the Republic of Serbia.

\section{References}

1. ZHOU P., LUUKKANEN O., TOKOLA T., NIEMINEN J. Effect of vegetation cover on soil erosion in a mountainous watershed. CATENA. 75, 319, 2008.

2. RAHMAN M.R., SHI Z.H., CHONGFA C. Soil erosion hazard evaluation - An integrated use of remote sensing, GIS and statistical approaches with biophysical parameters towards management strategies. Ecol. Model. 220, (13-14), 1724, 2009. 
3. TOY T.J., FOSTER G.R., RENARD K.G. Soil erosion: Processes. Prediction Measurement and Control. New York: Jon Wiley and Sons, pp. 1-23, 2002.

4. DRAGICEVIC S., FILIPOVIC D., KOSTADINOV S., RISTIC R., NOVKOVIC I., ZIVKOVIC N., ANDJELKOVIC G., ABOLMASOV B., SECEROV V., DJURDJIC S. Natural Hazard Assessment for Land-use Planning in Serbia. Int. J. Environ. Res. 5, (2), 371, 2011.

5. ZHANG X., WU B., LING F., ZENG Y., YAN N., YUAN C. Identification of priority areas for controlling soil erosion. CATENA. 83, (1), 76, 2010.

6. ALVAREZ-GUERRA M., VIGURI J.R., VOULVOULIS N. A multicriteria-based methodology or site prioritization in sediment management. Environ. Int. 35, (6) 920, 2009.

7. SHRIMALI S.S., AGGARWAL S.P., SAMRA J.S. Prioritizing erosion-prone areas in hills using remote sensing and GIS - a case study of the Sukhna Lake catchment, Northern India. Int. J. Appl. Earth Obs. Geoinf. 3, (1), 54, 2001.

8. NIGEL R., RUGHOOPUTH S. Mapping of monthly soil erosion risk of mainland Mauritius and its aggregation with delineated basins. Geomorphology. 114, (3), 101, 2010.

9. VRIELING A., STERK G., VIGIAK O. Spatial evaluation of soil erosion risk in the West Usambara Mountains, Tanzania. Land Degrad. Dev. 17, (3), 301, 2006.

10. MERRITT W.S., LETCHER R.A. JAKEMAN A.J. A review of erosion and sediment transport models. Environ. Modell. Softw. 18, (8-9), 761, 2003.

11. NI J.R., LI Y.K. Approach to soil erosion assessment in terms of land use structure changes. J. Soil Water Conserv. 58, (3), 158, 2003.

12. NI J.R., LI X.X., BORTHWICK A.G.L. Soil erosion assessment based on minimum polygons in the Yellow river basin, China. Geomorphology. 93, (3-4), 233, 2008.

13. WU Q., WANG M. A framework for risk assessment on soil erosion by water using an integrated and systematic approach. J. Hydrol. 337, (1-2), 11, 2007.

14. ZHANG K.L., SHU A.P., XU X.L., YANG Q.K., YU B. Soil erodibility and its estimation for agricultural soil in China. J. Arid Environ. 72, (6), 1002, 2008.
15. GAO S., ZHANG Z., CAO C. New Methods of Estimating Weights in AHP. In: Yu, F, Shu J., Yue G. (Ed.) Proceedings of the 2009 International Symposium on Information Processing (ISIP'09), 201, 2009.

16. VALENTE R.O.A., VETTORAZZI C.A. Definition of priority areas for forest conservation through the ordered weighted averaging method. Forest Ecol. Manag. 256, (6), 1408, 2008.

17. NEKHAY O., ARRIAZA M., GUZMÁN - ÁLVAREZ J.R. Spatial analysis of the suitability of olive plantations for wildlife habitat restoration. Comput. Electron. Agric. 65, (1), 49, 2009.

18. STRAGER M.P., ROSENBERGER R.S. Incorporating stakeholder preferences for land conservation: Weights and measures in spatial MCA. Ecol. Econ. 58, (1), 79, 2006.

19. FEIZIZADEH B., BLASCHKE T., NAZMFAR H., REZAEI MOGHADDAM M.H. Landslide Susceptibility Mapping for the Urmia Lake basin, Iran: A multi-criteria Evaluation Approach using GIS. Int. J. Environ. Res. 7, (2), 319, 2013

20. SRĐEVIĆ B. Combining different prioritization methods in the analytic hierarchy process synthesis. Comput. Oper. Res. 32, (7), 1897, 2005.

21. BEHZADIAN M., KHANMOHAMMADI OTAGHSARA S., YAZDANI M., IGNATIUS J. A state-of the-art survey of TOPSIS applications. Expert Syst. Appl. 39, (17), 13051, 2012.

22. CHEN Y., KILGOUR D.M., HIPEL K.W. En extreme-distance approach to multiple criteria ranking. Math. Comput. Model. 53, (5-6), 646, 2011.

23. OPRICOVIC S., TZENG G-H. Compromise solution by MCDM methods: A comparative analysis of VIKOR and TOPSIS. Eur. J. Oper. Res. 156, (2), 445, 2004.

24. GUMUS A.T. Evaluation of hazardous waste transportation firms by using a two step fuzzy-AHP and TOPSIS methodology. Expert Syst. Appl. 36, (2) 4067, 2009.

25. SAATY T. Decision-making with the AHP: Why is the principal eigenvector necessary. Eur. J. Oper. Res. 145, (1), 85, 2003. 
